\title{
Monocanalicular and Bicanalicular Silicone Tube Intubation Results in Patients With Congenital Nasolacrimal Duct Obstruction
}

\author{
Özlen Rodop Özgür, ${ }^{1}$ Berkay Akmaz,, Baran Kandemir, ${ }^{1}$ Ümit Çallı,, Yusuf Özertürk
}

'Department of Ophthalmology, Kartal Dr. Lütfi Kırdar Training and Research Hospital, İstanbul, Turkey

2Department of Ophthalmology Katip Çelebi University Atatürk Training and Research Hospital İzmir, Turkey

Submitted: 30.07.2015 Accepted: 28.11.2016

Correspondence: Berkay Akmaz, Katip Çelebi Üniversitesi Atatürk Eğitim ve Araştırma Hastanesi, Göz Hastalıkları Kliniği, İzmir, Turkey

E-mail: berkayakmaz@hotmail.com

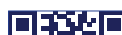

ifs?

口ifing

Keywords: Bicanalicular intubation; congenital; monocanalicular intubation; nasolacrimal duct obstruction.

\begin{abstract}
Objective: This study aims to compare the retrospective results of patients on whom silicone intubation was performed using either the monocanalicular or bicanalicular method and for whom probing and lavage procedures had failed for the treatment of congenital nasolacrimal duct obstruction (CLDO).
\end{abstract}

Methods: A total of 47 eyes of 42 patients - 25 females; 17 males - on whom silicone tube intubation was performed due to congenital nasolacrimal duct obstruction (CLDO) were involved in the study. As part of the study, a monocanalicular tube was placed in 23 of the 47 eyes ( $\left.\right|^{\text {st }}$ group), while a bicanalicular tube was placed in 24 of the eyes ( $2^{\text {nd }}$ group). The average age in the first group was 6.13 years ( $I-15$ years) and $4.5 I$ years ( $I-15$ years) in the second group. Extubation was performed in the postoperative 4.2 month (2-7 months) in the first group and in the postoperative 4.4 month (2-7 months) in the second group. Average length of follow-up of cases was determined to be 10.1 months (6-72 months).

Results: The procedure had a success rate of $82 \%$ (19 of 23 eyes) in the first group, while the success rate of the procedure conducted in the second group was $79 \%$ ( 19 of 24 eyes), with the difference between the groups determined not to be statistically significant $(p=0.76)$ (Kikare Test). Premature removal of tube was seen in three cases in the first group, with two patients having to be re-intubated and the other not having to be due to the absence of any more complaints. Tube prolapsus from the medial canthal region was seen in two patients from the second group in the second week after operation, resulting in them being extubated in the early period. Pyogenic granuloma was seen in one case in the first group and conjunctivitis in another case in the same group. However, no conjunctival or corneal complications were determined in either patients.

Conclusion: The success rate of monocanalicular and bicanalicular silicone tube intubation in patients who had undergone an ineffective probing procedure was determined to be similar, and there was no difference found between the two procedures in terms of their complication rates.

\section{INTRODUCTION}

Congenital nasolacrimal duct obstruction (CLDO) manifests itself in tear pooling and outflow during the first few weeks after birth, mucoid secretion reflux with pressure on the sac, conjunctivitis attacks, mucoid discharge and burrs on the eyelash margins. Conjunctivitis is an important clinical condition that can lead to serious complica- tions, such as dacryocystitis, preseptal cellulitis and orbital cellulitis, if untreated. ${ }^{[1]}$

The occurrence of congenital nasolacrimal duct obstruction has been reported to be between $1.7 \%$ and $20 \%$ in newborns. ${ }^{[2]}$ In $90 \%$ of patients, the membrane obstructing the Hasner's valve is opened within the first 12 months through conservative treatment. ${ }^{[3]}$ Conservative treatment includes lacrimal sac massage, lid hygiene and topical 
antibiotics. ${ }^{[4]}$ Studies have shown probing to be successful in between $70 \%$ and $97 \%$ of cases. Nasolacrimal duct intubation is recommended in older children and in children whose obstruction is not opened with probing. Success rates of between $69 \%$ and $100 \%$ have been reported in this method. ${ }^{[5-9]}$

In this study, we aimed to compare the results of monocanalicular and bicanalicular silicone intubation in patients with CLDO whose probing and lavage procedures were unsuccessful.

\section{MATERIAL AND METHODS}

The study included 47 eyes from 42 cases, 25 of which were female and 17 male, which had undergone silicone tube intubation due to CLDO between March 2008 and June 20I3. Congenital nasolacrimal duct obstruction was diagnosed through patient history and clinical findings. Suspected cases were tested for loss of fluorescein. One drop of a $2 \%$ solution of fluorescein was placed in the lower conjunctival fornix on both eyes. Cases wherein the dye had not cleared from the tear pool after five minutes were evaluated for congestion.

This study was carried out retrospectively, in compliance with the Helsinki Declaration principles and after first obtaining informed consent from parents. Cases involving nasolacrimal system trauma, acute dacryocystitis, lacrimal sac mucosa, punctum or canalicular obstruction, or craniofacial anomalies were excluded from the study. In the eyes included in the study, 3 of them were applied probing and lavage for 2 times and the others were applied for only once but there was failure with the procedures. The mean age of the patients at the time they had undergone probing and lavage was $20.2 \pm 7.6$ months (1 $2-42$ months). Based on the retrospective data, 23 of 47 eyes (group I) were inserted monocanalicular tube, while 24 of them (group 2) were inserted bicanalicular.

All patients underwent silicone tube intubation under general anesthesia. Bicanalicular silicone intubation was performed by applying the Ritleng method. The Ritleng metal probe was inserted through the nasolacrimal canal to the lower meatus. After feeling metal-to-metal contact, the probe was removed from the guide tube and the proximal end attached to the silicone tube was passed through the metal probe and advanced to the nasal cavity. The prolene tip either spontaneously emerged from the nose or was led to the nasopharynx and removed with the help of a metal hook. The same procedure was repeated from the other punctum and ligated with two knots and released in the nose. In the monocanalicular intubation, the silicone tube was removed from the proximal lower canal through the Ritleng intubation probe and withdrawn from the lower incision, and the tube was cut slightly in the nose. The collar at the upper end of the tube was placed on the punctum.

The demographic characteristics of the cases are shown in Table I. The average age of the cases in group I was 6.13 years ( $1-15$ years), while that of the cases in group 2 was $4.5 \mathrm{I}$ years ( $\mathrm{I}-15$ years). The mean time for tube extraction following performance of the respective procedure was 4.2 months (2-7 months) in the first group and 4.4 months (2-7 months) in the second group. The mean follow-up period of the patients was 10.1 months (6-72 months). Following the removal of the tubing, success was defined as complete absence of complaints of irrigation and normal level tear meniscus heights.

The Statistical Package for Social Sciences I7.0 (SPSS Inc., Chicago, IL, USA) program was used for all statistical analyzes. Results were evaluated with the Chi-square test. $P$ values lower than 0.05 were considered to be statistically significant.

\section{RESULTS}

The success rate in the first group was $82 \%$ and $79 \%$ in the second group, with the difference between the groups determined not to be statistically significant $(p=0.76)$. During examination of the cases, it was discovered that three of the impaired eyes in the first group underwent a dacryocystorhinostomy and one tube had to be placed again, while in the second group, four of the eyes underwent a dacryocystorhinostomy. In group I, it was observed that the tube was prematurely moved in three cases, two of which resulted in the tube being reintroduced, while in the other, since there were no more complaints, the tube was not reinserted. In the second group, tube prolapsus was observed in the medial canthal region two weeks after surgery, resulting in the tubes having to be removed in the early period. In the first group, there was one case of

Table I. Demographic features of the cases that had undergone a nasolacrimal system intubation

\begin{tabular}{lcc}
\hline & Group with monocanalicular tube & Group with bicanalicular tube \\
\hline Number of cases & 23 & 24 \\
Mean age (year) & 6.1 & 4.5 \\
Duration tube remained (in months) & 4.2 & 4.4 \\
\hline
\end{tabular}


Table 2. Complications that were observed in the cases with nasolacrimal system intubation

Group with monocanalicular tube

3

Early tube prolapse/exertion of tube

Pyogenic granuloma

Conjunctivitis
I
Group with bicanalicular tube

2

0

0
Pyogenic granuloma and one case of conjunctivitis (Table 2). Apart from this, there was no corneal or conjunctival complications seen in any of the cases.

\section{DISCUSSION}

Lacrimal system intubation is a commonly preferred method for congenital nasolacrimal system obstructions which are resistant to conservative treatment and/or probing. [10-12] While bicanalicular intubation has been practiced since the 1970s, monocanalicular intubation did not start to become popular until the 1990s. ${ }^{\left[{ }^{11}\right]}$

Both methods have their advantages and disadvantages. [6,8,10-12] In monocanalicular intubations, placement of the tube in the system can be sufficiently performed by entering only one punctum, where the tube is inserted from the upper and lower punctum in the ventricular intubation. ${ }^{[1,12]}$ One of the most important advantages of the bicanalicular tube is that its surface is flatter ${ }^{[12-14]}$ Monocanalicular tubes can cause abrasions or ulcers in the cornea, especially if they are placed in the upper canal and the collar side of the tube is larger. ${ }^{[14]}$ Engel et al., ${ }^{[10]}$ reported conjunctiva or corneal abrasion in $2 \%$ of 635 eyes where monocanalicular stapes were placed by upper canaliculus. In the study by Komínek et al.," ${ }^{[12]}$ where the lower canaliculi was placed in the monocanalicular tube, corneal abrasion was observed in $2.8 \%$ of patients. The Pediatric Ophthalmology Study Group identified corneal complications in I out of 309 patients who received a monocanalicular tube. ${ }^{[15]}$ Lastly, medial corneal abrasion was seen in two of the 35 patients who had monocanalicular tube placement in the study conducted by Goldstein et al. ${ }^{[16]}$ In our study, we observed no complications of the cornea or conjunctiva.

Another possible complication associated with nasolacrimal duct obstruction is the formation of pyogenic granulomas. Komínek et al. ${ }^{[12]}$ reported that 35 of the 35 patients who underwent monocanalicular tubing had pyogenic granulomas, whereas none of the 35 patients who received a bicanalicular tube had pyogenic granulomas. The study conducted by Yalaz et al.," ${ }^{[1]}$ found that granulomas occurred in only one of the 29 patients in whom a Ritleng tube was inserted. In our study, a pyogenic granuloma was seen in one patient who had a monocanalicular tube, while there was no formation of pyogenic granuloma in any of the patients who had a bicanalicular tube.
Silicone tubing involves the complication of punctum or canalicular laceration. Lim et al., ${ }^{[18]}$ reported canalicular laceration in six of the 122 patients who received bicanalicular tubing, while Andalib et al. did not encounter punctum or canalicular complications in the series of 70 cases they studied. ${ }^{[19]}$ In our study, no canalicular laceration was found in either group.

One other complication of the tube is the emergence or dislocation of the tube from its place. In the literature, the complication rate related to early tube expulsion is reported to be between $3 \%$ and $44 \%$. Among the causes, the low tolerance of foreign bodies in children and the unfamiliarity of the eyes to climatic and environmental factors are at the forefront. ${ }^{[10,19-2 \mid]}$ In order to reduce incidences of this complication, it has been suggested that the silicone tube be fixed with a suture that is absorbable to the nasal mucosa. Nevertheless, the literature reports that $21 \%$ of cases developed early tubing. ${ }^{[22]}$ Komínek et al., ${ }^{[1]}$ in their study, reported that eight of the 35 monocanalicular tubes spontaneously emerged in the early period, while 35 of the bicanalicular tubes they placed had to be removed early due to being displaced from the site. A study conducted by Yalaz et al. observed that for Ritleng tubal attachments, tubal dislocation occurred at two weeks in 2 patients of 29 eyes. ${ }^{[17]}$ Huang et al. found in their study that in $19 \%$ of the 25 patients who had monocanalicular tubing, the tube was released in the early period. In our study, 13\% of the cases with monocanalicular tubing had early outbreaks, whereas $8 \%$ of cases with bicanalicular tubing had tube prolapse in early period.

There are various opinions about when the tube should be removed. While some authors state that they should stay in the nasolacrimal duct for 4-6 months, other authors suggest that three months is enough. ${ }^{[13,20,21]}$ Migliori et al. were able to achieve a $100 \%$ success rate in their study by leaving the tubes in place for six weeks. ${ }^{[23]}$ However, the common view is that the success rate is lower when the duration is shorter than two months.

The literature includes many domestic and foreign studies that have been conducted on the success rate of nasolacrimal duct intubation. For example, Kraft et al. ${ }^{[24]}$ reported a success rate of $80.3 \%$ in cases of bicanalicular tube administration; Lee et al., ${ }^{[25]}$ reported a $98 \%$ success rate; Aggarwal et al. ${ }^{[26]}$ reported an $89 \%$ success rate; and Dortzbach 
et al. ${ }^{[27]}$ reported a success rate of $82.5 \%$. Yüksel et al.,, ${ }^{[28]}$ in their study, had a $68.9 \%$ success rate in the group of patients who were between 24 months and 5 years of age, while Karadayı et al. ${ }^{[29]}$ reported a success rate of $93.9 \%$ in the 2 to 12 year-old age group. Performing bicanalicular intubation using the Ritleng method, Yazici et al., in their study, had a success rate of $86 \%{ }^{[22]}$ To continue, Okumuş et al. ${ }^{[30]}$ reported a $71.9 \%$ success rate with bicanalicular silicone tube intubation in cases spanning a period of over 36 months.

With monocanalicular silicone tube intubation, Kaufman et al. ${ }^{[13]}$ reported a $79 \%$ success rate, while using the same method, Goldstein et al. ${ }^{[16]}$ reported a $91 \%$ success rate in a series of 35 patients. While Fayet and colleagues ${ }^{[3 /]}$ noted an $85 \%$ success rate with monocanalicular intubation applied by different methods (e.g. pushing with a stent), Andalib et al., ${ }^{[32]}$ in their study, compared conventional mononaural intubation with Fayet's method and reported success rates of $90 \%$ and $50 \%$, respectively.

There are only a limited number of studies comparing monocanalicular and bicanalicular tube intubation results. In comparisons of the success rates of monocanalicular and bicanalicular intubation, the rates have been shown to be similar. Furthermore, Kashkouli et al. reported a 61.5\% success rate for monocanalicular and a $59.0 \%$ success rate for bicanalicular. ${ }^{[1]}$ In a study by Komínek et al., they found there to be an $88.5 \%$ success rate for bicanalicular intubation and a $97.1 \%$ success rate for monocanalicular intubation in a review of similar studies. ${ }^{[12]}$ Lastly, in a study by Andalib et al., where monocanalicular and bicanalicular tube intubations were performed in patients older than two years of age at the time of admission, they reported a success rate of $87.5 \%$ with the monocanalicular tube and an $89 \%$ success rate with the bicanalicular tube. ${ }^{[18]}$ In our study, we did not find any significant difference between the two groups in terms of the success rates (bicanalicular 79\%; monocanalicular 82\%).

The results from our study showed there to be no difference in the success rates of monocanalicular and bicanalicular silicone tube intubation in cases of unsuccessful probing, and determined there to be similar complication rates.

Ethics Committee Approval

Approval has been obtained from the Kartal Dr. Lütfi Kırdar Training and Research Hospital Ethics Committee.

\section{Informed Consent}

Approval was obtained from the patients.

Peer-review

Internally peer-reviewed.

Authorship Contributions

Concept: Ö.R.Ö.; Design: B.A.; Data collection \&/or processing: Ü.Ç.; Literature search: B.K.; Writing: Ö.R.Ö; Critical review: Y.Ö.
Conflict of Interest

None declared.

\section{REFERENCES}

1. Katowitz JA, Kropp TA. Congenital abnormalities of the lacrimal drainage system. In: Hornblass A, ed. Oculoplastic, Orbital and Reconstructive Surgery (2nd ed). Baltimore; Williams and Wilkins; 1990:1397-416.

2. Stager D, Baker JD, Frey T, Weakley DR Jr, Birch EE. Office probing of congenital nasolacrimal duct obstruction. Ophthalmic Surg 1992;23:482-4.

3. Buerger DG, Schaeffer AJ, Campbell CB, Flanagan JC. Congenital Lacrimal disorders. In: Nesi FA, Lisman RD, Levine MR, eds. Smith's Ophthalmic Plastic and Reconstructive Surgery (2nd ed). St Louis; Mosby; 1998:649-60.

4. Yen KG, Yen MT. Managing the tearing infant.Nasolacrimal duct obstruction. Contemp Ophthalmol 2002;1:1-5.

5. Forbes BJ, Khazaeni LM. Evaluation and management of an infant with tearing and eye discharge. Pediatr Case Rev 2003;3:40-3.

6. al-Hussain H, Nasr AM. Silastic intubation in congenital nasolacrimal duct obstruction: a study of 129 eyes. Ophthal Plast Reconstr Surg 1993;9:32-7. [CrossRef]

7. Leone CR, Van Gemert JV. Thesuccess rate of silicon intubation in congenital lacrimal obstruction. Ophthalmic Surg 1990;21:90-2.

8. Pelit A, Caylakli F, Yaycioglu RA, Akova Y. Silicone intubation with the Ritleng method using intranasal endoscopy to treat congenital nasolacrimal duct obstruction. Int J Pediatr Otorhinolaryngol 2009;73:1536-8. [CrossRef]

9. Sabermoghaddam AA, Hosseinpoor SS. Preventing silicone tube extrusion after nasolacrimal duct intubation in children. J Ophthalmic Vis Res 2010;5:280-3.

10. Engel JM, Hichie-Schmidt C, Khammar A, Ostfeld BM, Vyas A, Ticho BH. Monocanalicular silastic intubation for the initial correction of congenital nasolacrimal duct obstruction. J AAPOS 2007;11:183-6. [CrossRef]

11. Kashkouli MB, Kempster RC, Galloway GD, Beigi B. Monocanalicular versus bicanalicular silicone intubation for nasolacrimal duct stenosis in adults. Ophthal Plast Reconstr Surg 2005;21:142-7.

12. Komínek P, Cervenka S, Pniak T, Zeleník K, Tomášková $H$, Matoušek P. Monocanalicular versus bicanalicular intubation in the treatment of congenital nasolacrimal duct obstruction. Graefes Arch Clin Exp Ophthalmol 2011;249:1729-33. [CrossRef]

13. Kaufman LM, Guay-Bhatia LA. Monocanalicular intubation with Monoka tubes for the treatment of congenital nasolacrimal duct obstruction. Ophthalmology 1998;105:336-41. [CrossRef]

14. Fayet B, Hurbi T, Renard G, Ruban JM, Racy E, Bernard JA. Suggested precautions when using a monocanalicular stent. Ophthal Plast Reconstr Surg 2001;17:76-8. [CrossRef]

15. Repka MX, Melia BM, Beck RW, Atkinson CS, Chandler DL, Holmes JM, et al. Primary treatment of nasolacrimal duct obstruction with nasolacrimal duct intubation in children younger than 4 years of age. J AAPOS 2008;12:445-50. [CrossRef]

16. Goldstein SM, Goldstein JB, Katowitz JA. Comparison of monocanalicular stenting and balloon dacryoplasty in secondary treatment of congenital nasolacrimal duct obstruction after failed primary probing. Ophthal Plast Reconstr Surg 2004;20:352-7. [CrossRef]

17. Yalaz M, Ozcan AA, Akcali C, Soylu L. Lacrimal intubation with the 
Ritleng system in recurrent congenital nasolacrimal duct obstruction in children. ORL J Otorhinolaryngol Relat Spec 2004;66:35-7.

18. Lim CS, Martin F, Beckenham T, Cumming RG. Nasolacrimal duct obstruction in children: outcome of intubation. J AAPOS 2004;8:466-72. [CrossRef]

19. Andalib D, Gharabaghi D, Nabai R, Abbaszadeh M. Monocanalicular versus bicanalicular silicone intubation for congenital nasolacrimal duct obstruction. J AAPOS 2010;14:421-4. [CrossRef]

20. Lee H, Ahn J, Lee JM, Park M, Baek S. Clinical effectiveness of monocanalicular and bicanalicular silicone intubation for congenital nasolacrimal duct obstruction. J Craniofac Surg 2012;23:1010-4.

21. Dotan G, Ohana O, Leibovitch I, Stolovitch C. Early loss of monocanalicular silicone tubes in congenital nasolacrimal duct obstruction: incidence, predictors, and effect on outcome. Int J Pediatr Otorhinolaryngol 2015;79:301-4. [CrossRef]

22. Yazici B, Akarsu C, Salkaya M. Silicone intubation with the Ritleng method in children with congenital nasolacrimal duct obstruction. J AAPOS 2006; 10:328-32. [CrossRef]

23. Migliori AJ, PuttermanAM. Silicone intubation for the treatment of congenital nasolacrimal duct obstruction: successful results removing the tubes after 6 weeks. Ophthalmology 1988;95:292-5. [CrossRef]

24. Kraft SP, Crawford JS. Silicone tube intubation in disorders of the lacrimal system in children. Am J Ophthalmol 1982;94:290-9.

25. Lee JJ, Ahn JH, Kim JL, Yang JW. The clinical outcome of endoscopic silicone tube intubation for congenital nasolacrimal duct obstruction.
J Korean Opthalmol Soc 2010;53:929-33. [CrossRef]

26. Aggarwal RK, Misson GP, Donaldson I, Willshaw HE. The role of nasolacrimal intubation in the management of childhood epiphora. Eye (Lond) 1993;7( Pt 6):760-2. [CrossRef]

27. Dortzbach RK, France TD, Kushner BJ, Gonnering RS. Silicone intubation for obstruction of the nasolacrimal duct in children. Am J Ophthalmol 1982;94:585-90. [CrossRef]

28. Yüksel D, Ceylan K, Kasım R, Duman S. Konjenital nasolacrimal kanal tıkanıklıklarında uygulanacak cerrahi tipinin seçimi : cerrahi tedavi sonuçlarımız. T Oft Gaz 2007;37:254-9.

29. Karadayı K, Çiftçi F, Yıldız FT, Sönmez M, Ünsal U, Güngör A, et al. Lacrimal kanal tıkanıklıklarında silicon entübasyonu. Problemeler, komplikasyonlar ve başarı oranları. T Oft Gaz 2003;33:498-505.

30. Okumuş S, Erbağcı İ, Güngör K, Bekir N. Nazolakrimal kanal tıkanıklığı olan hastalara yaş gruplarına gore uyguladığımız tedavi yöntemleri ve sonuçlarımız. Türkiye Klinikleri J Ophthalmol 2009;18:223-9.

31. Fayet B, Katowitz WR, Racy E, Ruban JM, Katowitz JA. Pushed monocanalicular intubation: an alternative stenting system for the management of congenital nasolacrimal duct obstructions. J AAPOS 2012;16:468-72. [CrossRef]

32. Andalib D, Mansoori H. A comparison between monocanalicular and pushed monocanalicular silicone intubation in the treatment of congenital nasolacrimal duct obstruction. Int J Ophthalmol 2014;7:1039-42.

\section{Doğumsal Nazolakrimal Kanal Tıkanıklı̆ı Olan Olgularda Monokanaliküler ve Bikanaliküler Silikon Tüp Entübasyon Sonuçları}

Amaç: Bu çalışmada, doğumsal nazolakrimal kanal tıkanıklı̆̆ında (DNLKT) sondalama ve lavaj işleminin basarısız olduğu ve monokanaliküler veya bikanaliküler yöntem ile silikon entübasyon uygulanmış olguların geriye dönük sonuçları karşılaştırıldı.

Gereç ve Yöntem: Doğumsal nazolakrimal kanal tıkanıklığı (DNLKT) nedeniyle silikon tüp entübasyonu yapılan 25’i kız, I7’si erkek 42 olgunun 47 gözü çalışmaya alındı. Çalışmada 47 gözün 23'üne (I. grup) monokanaliküler tüp, 24'üne (2. grup) ise bikanaliküler tüp yerleştirildi. Birinci grupta yaş ortalaması 6.13 yı ( $(1-15$ yaş), ikinci grupta yaş ortalaması $4.5 \mathrm{I}$ yıl ( I-I5 yaş) idi. Tüp çıkarımı birinci grupta ameliyat sonrası 4.2 ay (2-7 ay), ikinci grupta ortalama 4.4 ayda (2-7 ay) yapıldı. Olguların ortalama takip süresi 10.1 ay (6-72 ay) olarak saptandı.

Bulgular: Birinci gruptaki 23 gözün 19'unda (\%82), 2. gruptaki 24 gözün 19'unda (\%79) başarı tespit edildi. Gruplar arasındaki fark istatistiksel olarak anlamlı bulunmadı $(p=0.76)$. Birinci grupta üç olguda tüpün yerinden erken çıktığı görüldü. Bu olguların ikisine yeniden tüp yerleştirildi fakat diğer olgunun şikayetleri geçtiğinden tekrar tüp yerleştirilmedi. İkinci grupta iki olguda ameliyat sonrası ikinci haftada medial kantal bölgeden tüp prolapsusu görüldü ve erken dönemde tüpleri çıkartıldı.

Sonuç: Sondalama işlemi başarısız olan olgularda monokanaliküler ve bikanaliküler silikon tüp entübasyonu başarı oranları birbirine benzerdir ve komplikasyon oranları arasında fark yoktur.

Anahtar Sözcükler: Bikanaliküler entübasyon; doğumsal; monokanaliküler entübasyon; nazolakrimal kanal tıkanıklığı. 